\title{
Analysis of IPTV Channels Watching Preferences in Bosnia and Herzegovina
}

\author{
A. Tanovic \\ Department for IT Development of \\ Multimedia Services \\ BH Telecom d.d. Sarajevo \\ Bosnia and Herzegovina \\ anel.tanovic@bhtelecom.ba
}

\author{
I. Androulidakis \\ Jožef Stefan International \\ Postgraduate School \\ Jamova 39, Ljubljana SI-1000, \\ Slovenia \\ sandro@noc.uoi.gr
}

\author{
F. Orucevic \\ Department of Computer Science \\ and Informatics \\ University of Sarajevo \\ Bosnia and Herzegovina \\ forucevic@etf.unsa.ba
}

\begin{abstract}
IPTV service is a new service which is today offered from almost every Telecom operator. One of the advantages of IPTV service stemming from its architecture is certainly the fact that it is very easy to measure what $\mathrm{TV}$ channels are the ones mostly watched. This papers desribes this measurement and analysis results in one Telecom operator in Bosnia and Herzegovina. They describe what TV channels are mostly watched in different time periods. We developed a simple weighting algorithm to order the channels by watching rate. Based on it we are providing extensive tables. This paper forms an industrial contribution with results important for marketing but also is scientific contribution because it introduces one new method of scoring TV channels based on previous measurements in their audience. We also developed IPTV Statistics model and described results from this research for a new statistics model. This paper is the continuous of previously published contributions from this area.
\end{abstract}

Keywords - IPTV; TV channel; telecom operator; channel rating; statistics model.

\section{INTRODUCTION}

IPTV service is a new IP service which is introduced in almost every Telecom operator [2-4]. IPTV system has several subsystems like: Middleware system, Video on Demand system, Encryption system, Database system, Monitoring system, Statistics system and Headend system [3-4]. Middleware system and the Statistics system are the important elements for the process of measurement of watched TV channels. The relationship between these 2 systems is shown in Figure 1.

Figure 1. describes an IPTV system in one Telecom operator in Bosnia and Herzegovina where all measurements have been done. Middleware system is responsible for the normal working of all IPTV applications, Video on Demand system is responsible for all actions with Video on Demand contents, Encyption system is responsible for the encoding and decoding of live TV channels and VoD contents, Database system is responsible for the storing of all data, Monitoring system is responsible for the process of monitoring Set Top Boxes in each geographical area in Bosnia and Herzegovina and Headend system is responsible for the working of all satellite antennas, receivers and encoders [1, 3, 4]. Statistics system is responsible for communication with every Set Top Box and it has a MySQL database where millions of records are placed about the watched TV channels. With red colour in Figure 1 we are marking the Statistics system and with blue colour the Middleware system. Figure 1. describes the position of Statistics subsystem in the IPTV system and its connections to other IPTV subsystems, primarly to Middleware subsystem which is responsible for communication with STB's on which users are watching TV channels.

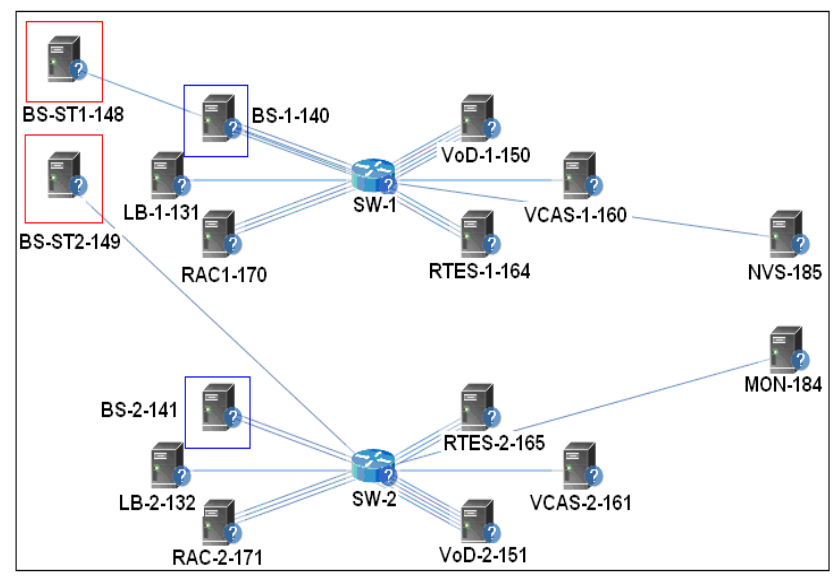

Fig. 1. The relationship between 2 IPTV subsystems

Previous research of authors from this field is based on description of changing Middleware system based on ITIL V3 recommendations [3] and the analysis of implementation of Information Security Management in IPTV system of Telecom operator [4]. This research continues with researches in this Telecom operator and the aim of all investigations is to improve business processes which are connected to IPTV. This contribution builts upon [10] to further explore rating of IPTV channels user's preference [11].

Section II describes the methodology of the measurement which is done in Telecom operator in Bosnia and Herzegovina and section III has a detailed description of the results in graphs. Section IV presents the conclusion of work in which is introduced one new method of scoring TV channels based on 
previous done measurements and new developed IPTV Statistics model.

\section{METHODOLOGY OF THE RESEARCH}

Statistics system is responsible for communication with every Set Top Box $[6,7]$. This system has internal scripts and a MySQL database which is responsible for storing all data [5]. Internal scripts communicate with every Set Top Box and if user watches one TV channel more than 60 seconds, these scripts write the relevant new record in the MySQL database. The value of 60 seconds is an approximate value stemming from previous research in the area, trying to answer the question of how many continuous seconds must elapse before we can say that the user is actually watching the given TV channel $[8,9]$. The main table in this database is table STAT which contains fields that are described in Table I.

TABLE I. TABLE STAT IN STATISTICS DATABASE

\begin{tabular}{|c|c|c|}
\hline The name of field & The meaning of field & $\begin{array}{c}\text { Type of the } \\
\text { variable }\end{array}$ \\
\hline EVENT_ID & $\begin{array}{c}\text { This field signs what } \\
\text { type of IPTV content is } \\
\text { used for statistics }-1 \text { is } \\
\text { for TV } 2 \text { is for VoD, } 3 \\
\text { is for Radio }\end{array}$ & INTEGER \\
\hline CHANNEL_TAG & $\begin{array}{c}\text { The name of TV } \\
\text { channel }\end{array}$ & VARCHAR2 \\
\hline SUBSCRIBER_ID & $\begin{array}{c}\text { Unique number for each } \\
\text { subscriber }\end{array}$ & INTEGER \\
\hline DEVICE_ID & $\begin{array}{c}\text { Unique number for each } \\
\text { Set Top Box }\end{array}$ & INTEGER \\
\hline CONTENT_ID & $\begin{array}{c}\text { Unique number for each } \\
\text { TV content }\end{array}$ & INTEGER \\
\hline TIMESTAMP & $\begin{array}{c}\text { The time when TV } \\
\text { content starts }\end{array}$ & DATETIME \\
\hline DURATION & $\begin{array}{c}\text { The duration of TV } \\
\text { content }\end{array}$ & INTEGER \\
\hline RATING & $\begin{array}{c}\text { The rating of TV } \\
\text { content }\end{array}$ & INTEGER \\
\hline INSERT_DATE & $\begin{array}{c}\text { Date and time when the } \\
\text { record is inserted into } \\
\text { MySQL database }\end{array}$ & DATETIME \\
\hline
\end{tabular}

All measurements are done with a few SQL queries which link all these fields:

“select channel_tag, sum(duration)/3600 from stat $\mathrm{s}$ where s.event $\mathrm{id}={ }^{\prime} 1^{\prime}$

and s.timestamp between '2011-05-01 00:00:00' and '2011-06-01 00:00:00' group by s.content_id"

The measurements have been done on 30,000 of users and they included 16840649 records during May 2011. This month has been taken into account because the number of IPTV users in Telecom operator [4] was the biggest in this month. The number of TV channels is 75 .

The research has been done in 11 categories (each category corresponding to different time periods) and for each category we included the first $20 \mathrm{TV}$ channels. For the rating algorithm, 20 points are given for the $1^{\text {st }}$ channel in order in each test category, 19 points are given for the $2^{\text {nd }}$ channel in order, 18 points are given for the $3^{\text {rd }}$ channel in order, 17 points are given for the $4^{\text {th }}$ channel in order etc. and for the last $20^{\text {th }}$ channel just 1 point. The summary results are given in table II.

TABLE II. THE NUMBER OF POINTS FOR EACH TV CHANNEL

\begin{tabular}{|c|c|}
\hline The name of TV channel & $\begin{array}{c}\text { The number of points for each } \\
\text { TV channel }\end{array}$ \\
\hline FTV & 219 \\
\hline NTV HAYAT & 200 \\
\hline OBN & 197 \\
\hline BHT & 189 \\
\hline NOVA TV & 178 \\
\hline PINK BIH & 171 \\
\hline MINIMAX & 141 \\
\hline OTV VALENTINO & 139 \\
\hline HRT 1 & 123 \\
\hline FOX LIFE & 122 \\
\hline TV 1 & 111 \\
\hline TVSA & 97 \\
\hline FOX CRIME & 73 \\
\hline RTV SLON & 69 \\
\hline NTV JASMIN & 65 \\
\hline DISNEY XD & 58 \\
\hline ARENA SPORT 3 & 46 \\
\hline HRT 2 & 37 \\
\hline DISC. TRAVEL \& LIVING & 26 \\
\hline RTV TK & 13 \\
\hline DISCOVERY & 11 \\
\hline RTL + & 6 \\
\hline ARENA SPORT 2 & 5 \\
\hline TV 1000 & 4 \\
\hline HISTORY CHANNEL & 4 \\
\hline NATIONAL GEOGRAPHY & 2 \\
\hline EUROSPORT & 2 \\
\hline ARENA SPORT 4 & 1 \\
\hline
\end{tabular}

III. RESULTS

Figure 2 presents the most watched TV channels during May 2011. Figure 3 shows the most watched TV channels in the $1^{\text {st }}$ week of May 2011 from $1^{\text {st }}$ May to $8^{\text {th }}$ May. Figure 4 presents the most watched TV channels in the $2^{\text {nd }}$ week of May 2011 from $8^{\text {th }}$ May to $15^{\text {th }}$ May. Figure 5 shows the most watched TV channels in the $3^{\text {rd }}$ week of May 2011 from $15^{\text {th }}$ May to $22^{\text {th }}$ May. Figure 6 shows the most watched TV channels in $4^{\text {th }}$ week of May 2011 from $22^{\text {nd }}$ May to $31^{\text {st }}$ May.

Figure 7 presents the most watched TV channels for working days through May 2011. As such, it includes every day except weekend days with total number of 24 days. Figure 8 shows the most watched TV channels for weekend days through May 2011 with the total number of 7 days.

Figure 9 describes the most watched TV channels for morning hours which includes hours from 6 a.m. to 12 a.m. Figure 10 presents the most watched TV channels for afternoon hours which includes hours from 12 a.m. to 8 p.m. Figure 11 describes the most watched TV channels for evening hours which includes hours from 8 p.m. to 11 p.m. Figure 12 presents the most watched TV channels for night hours which includes hours from 12 p.m. to 6 a.m. 
The column 'the number of points for each TV channel' in $47 \mathrm{TV}$ channels, of the total number of TV channels which are table II is the summary of points for each TV channel in all 75, are not presented in this table. Table II shows that first 5 measurements. In all measurements, we gave 20 points for the TV channels are local channels, and in first 10 channels is just 1 st TV channel, 19 points for the 2 nd TV channel, 18 points for 1 foreign TV channel.

the 3rd TV channel and etc., and finally 2 points for the 19th

TV channel and 1 point for the 20th TV channel. The total number of TV channels that have at least 1 point is 28 . So even

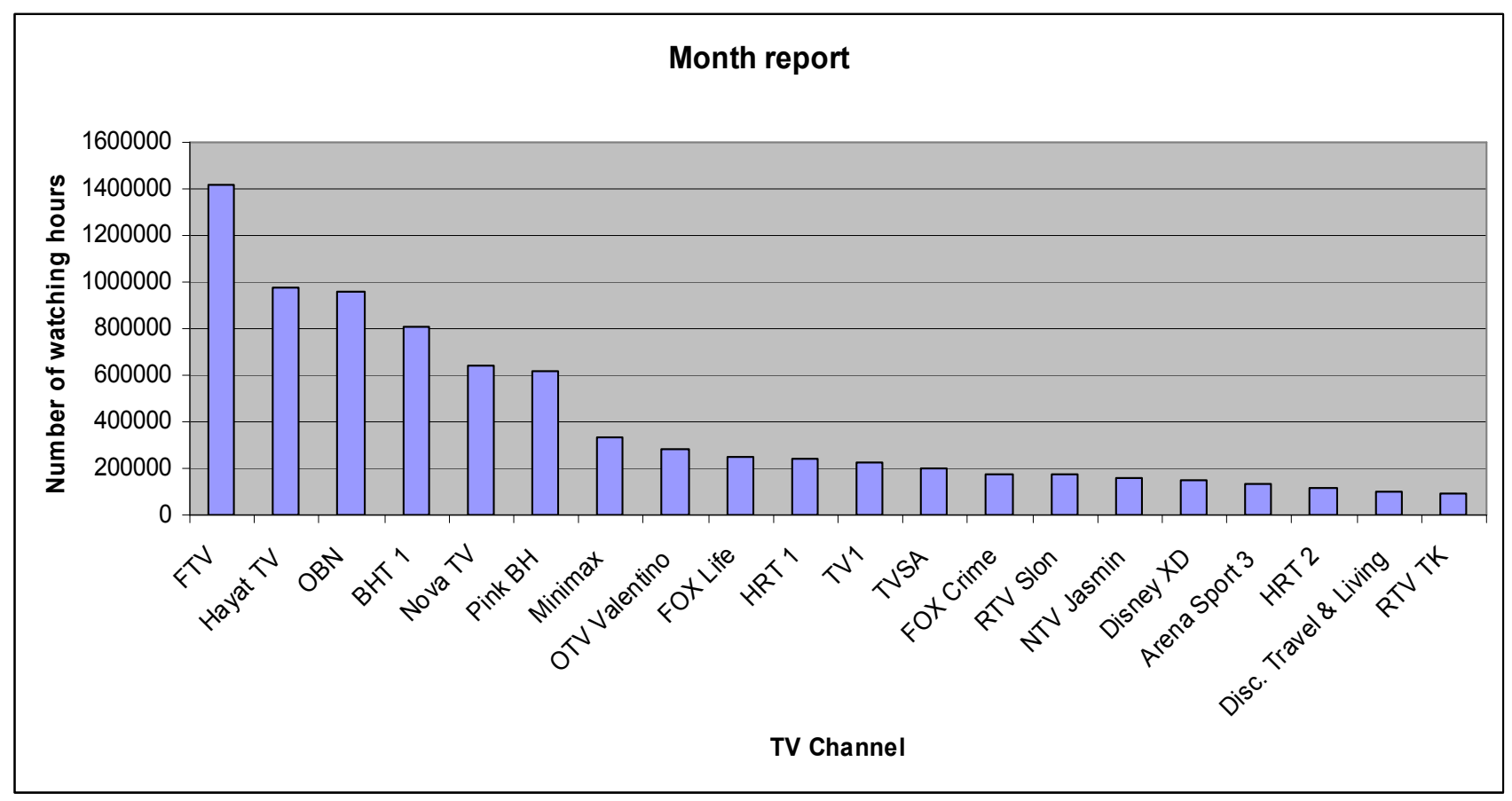

Fig. 2. The most watched TV channels in month (May 2011.)

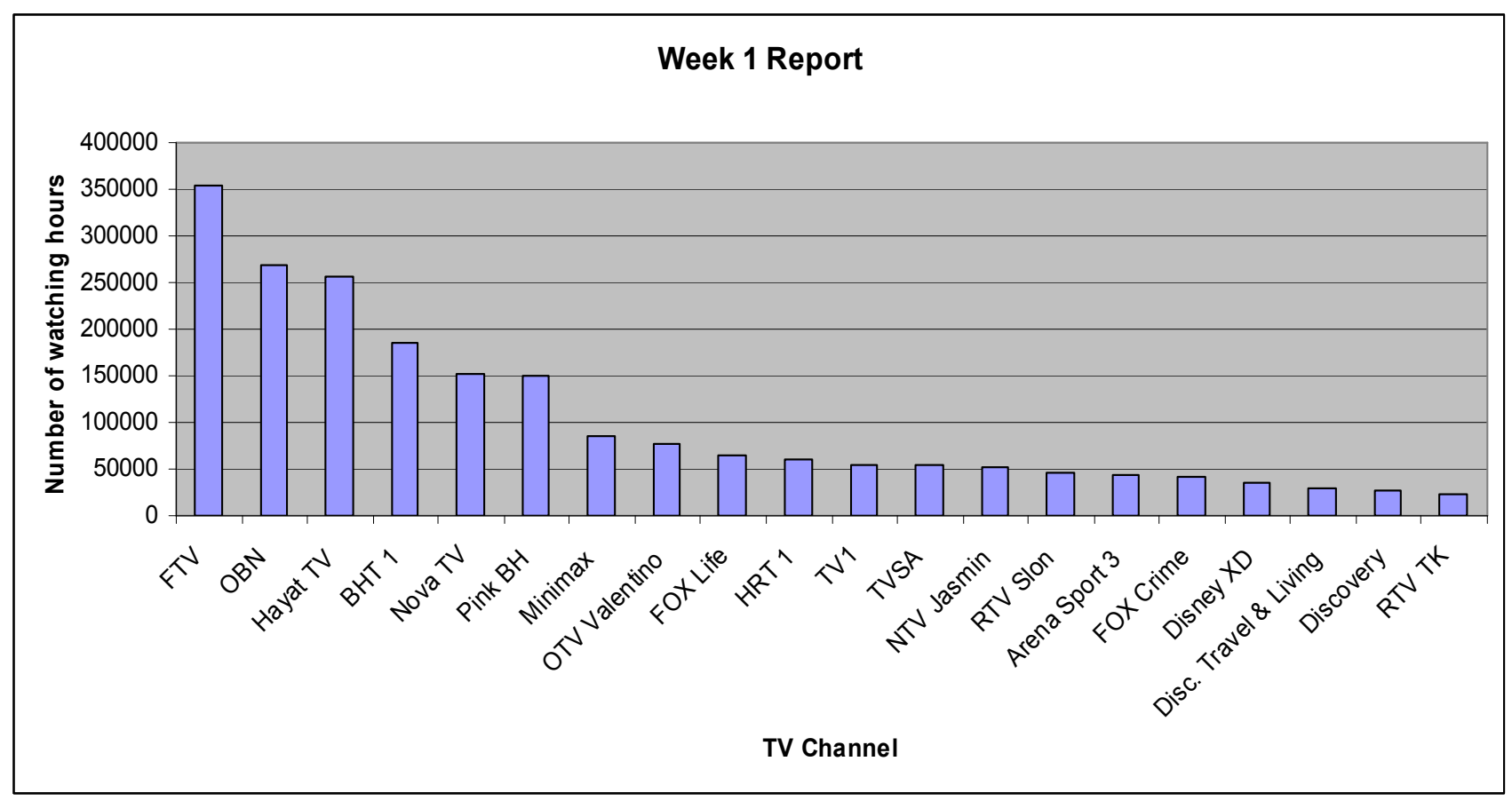

Fig. 3. The most watched TV channels in the $1^{\text {st }}$ week of month (May 2011.) 


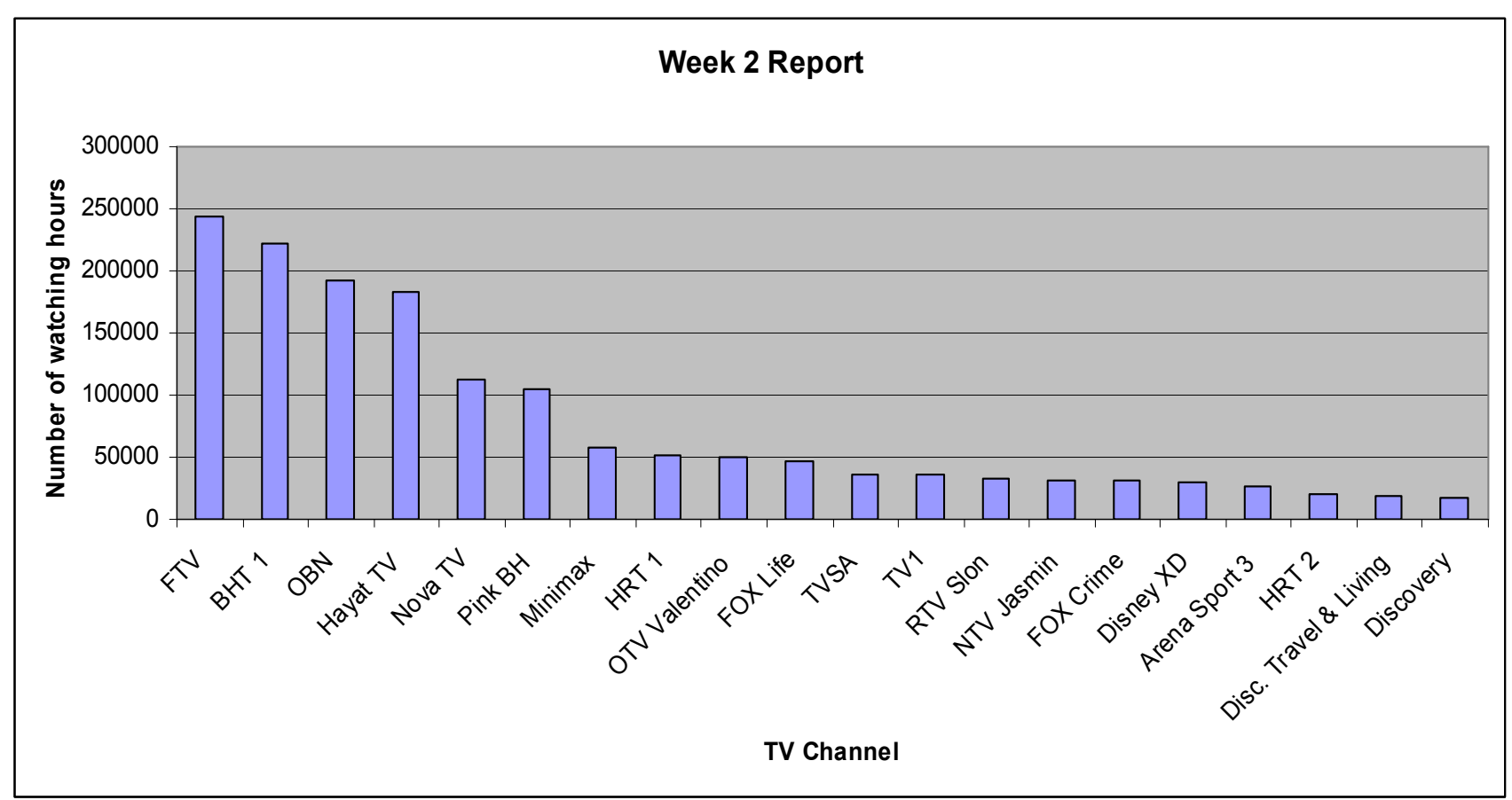

Fig. 4. The most watched TV channels in the $2^{\text {nd }}$ week of month (May 2011.)

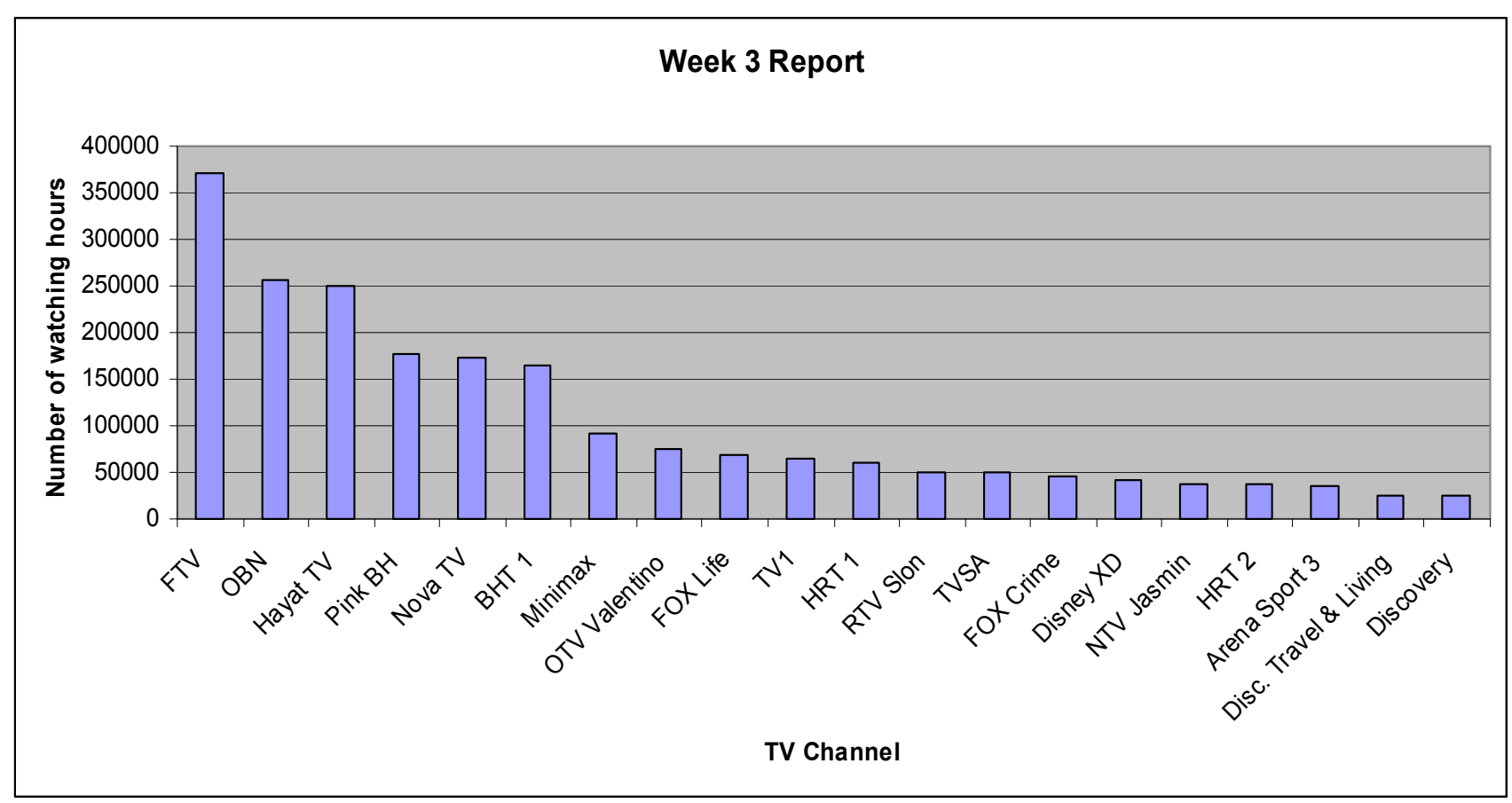

Fig. 5. The most watched TV channels in the $3^{\text {rd }}$ week of month (May 2011.) 


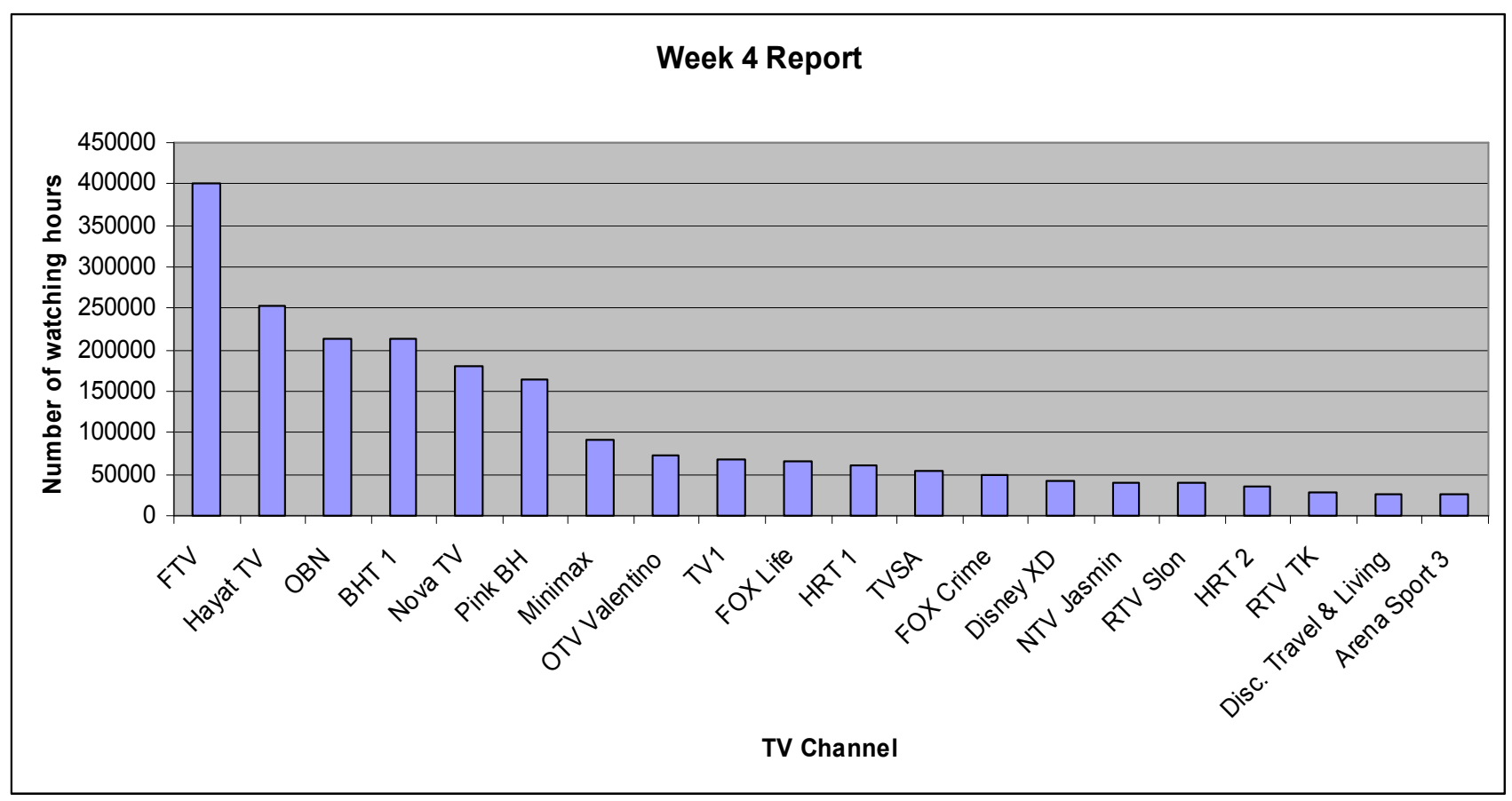

Fig. 6. The most watched TV channels in the $4^{\text {th }}$ week of month (May 2011.)

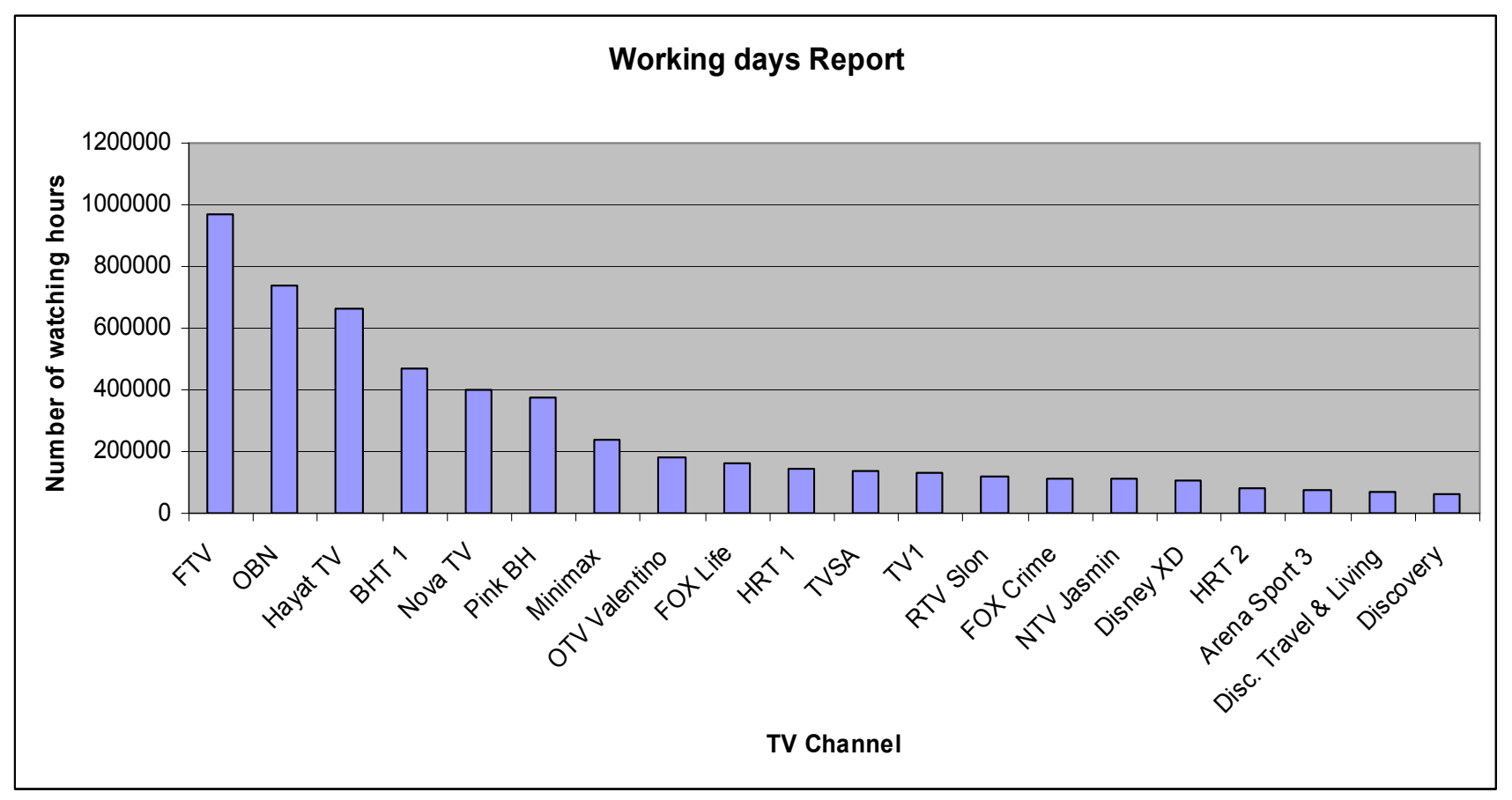

Fig. 7. The most watched TV channels in working days of month (May 2011.) 


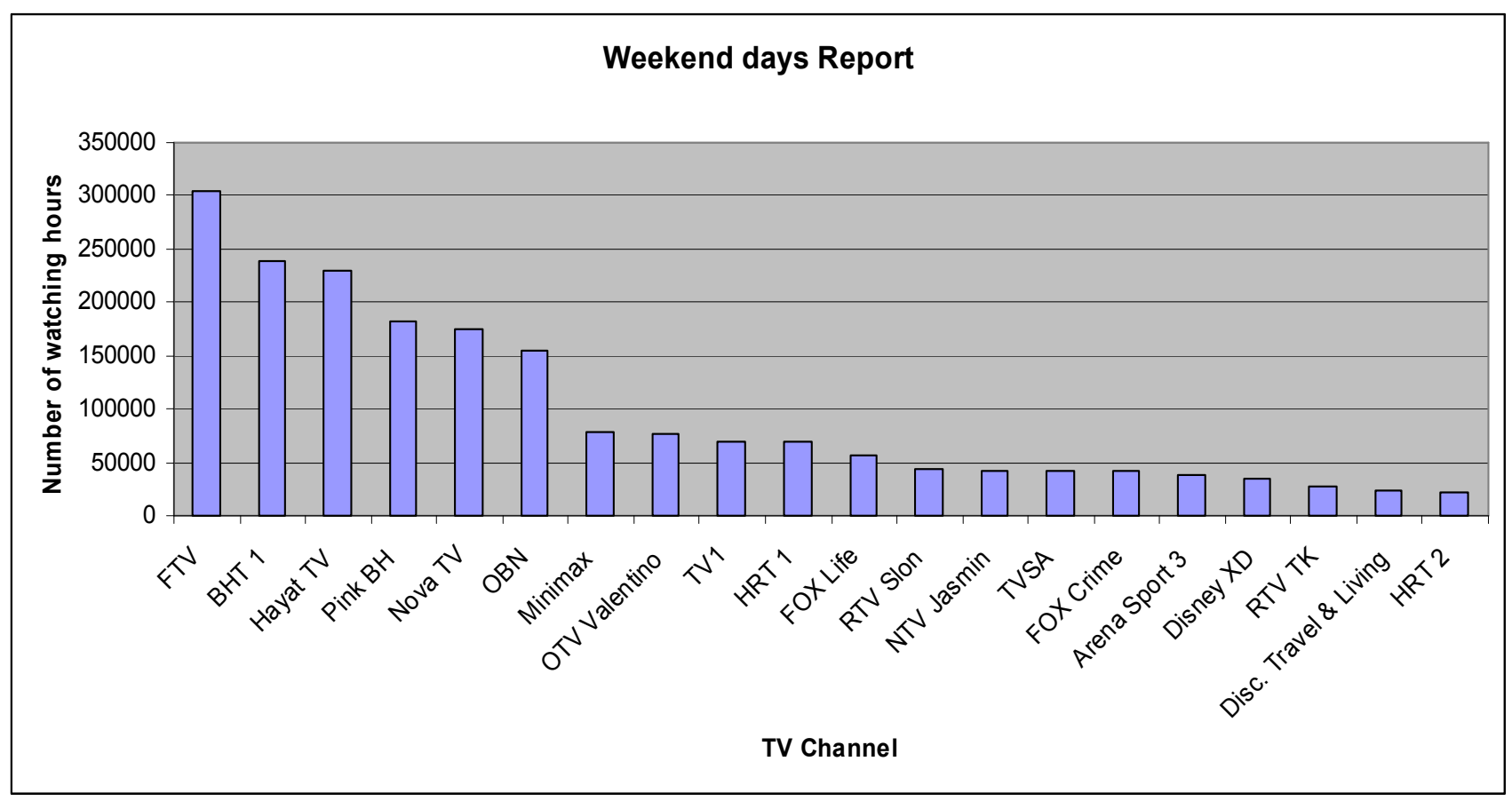

Fig. 8. The most watched TV channels in weekend days of month (May 2011.)

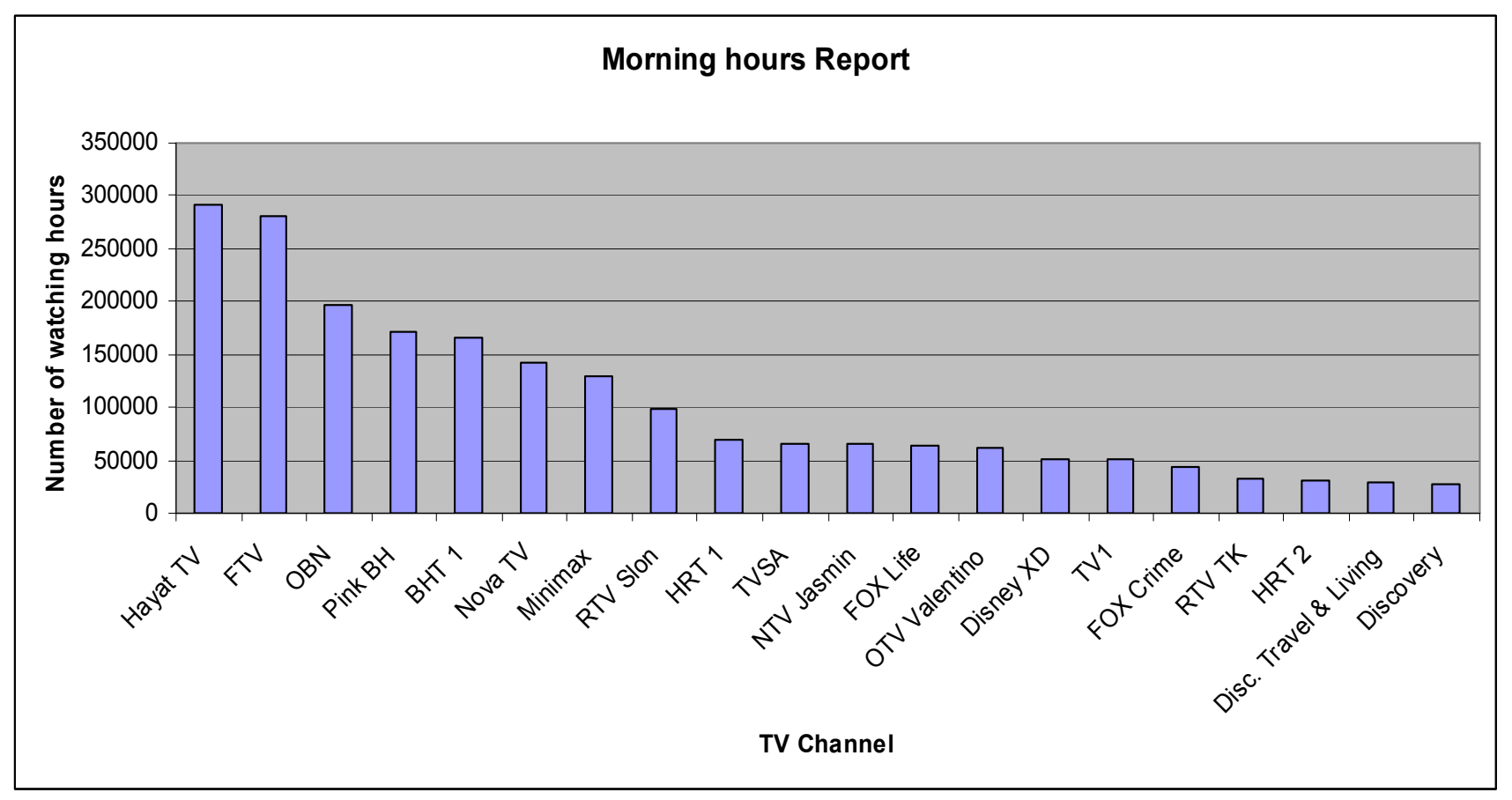

Fig. 9. The most watched TV channels in morning hours of month (May 2011.) 


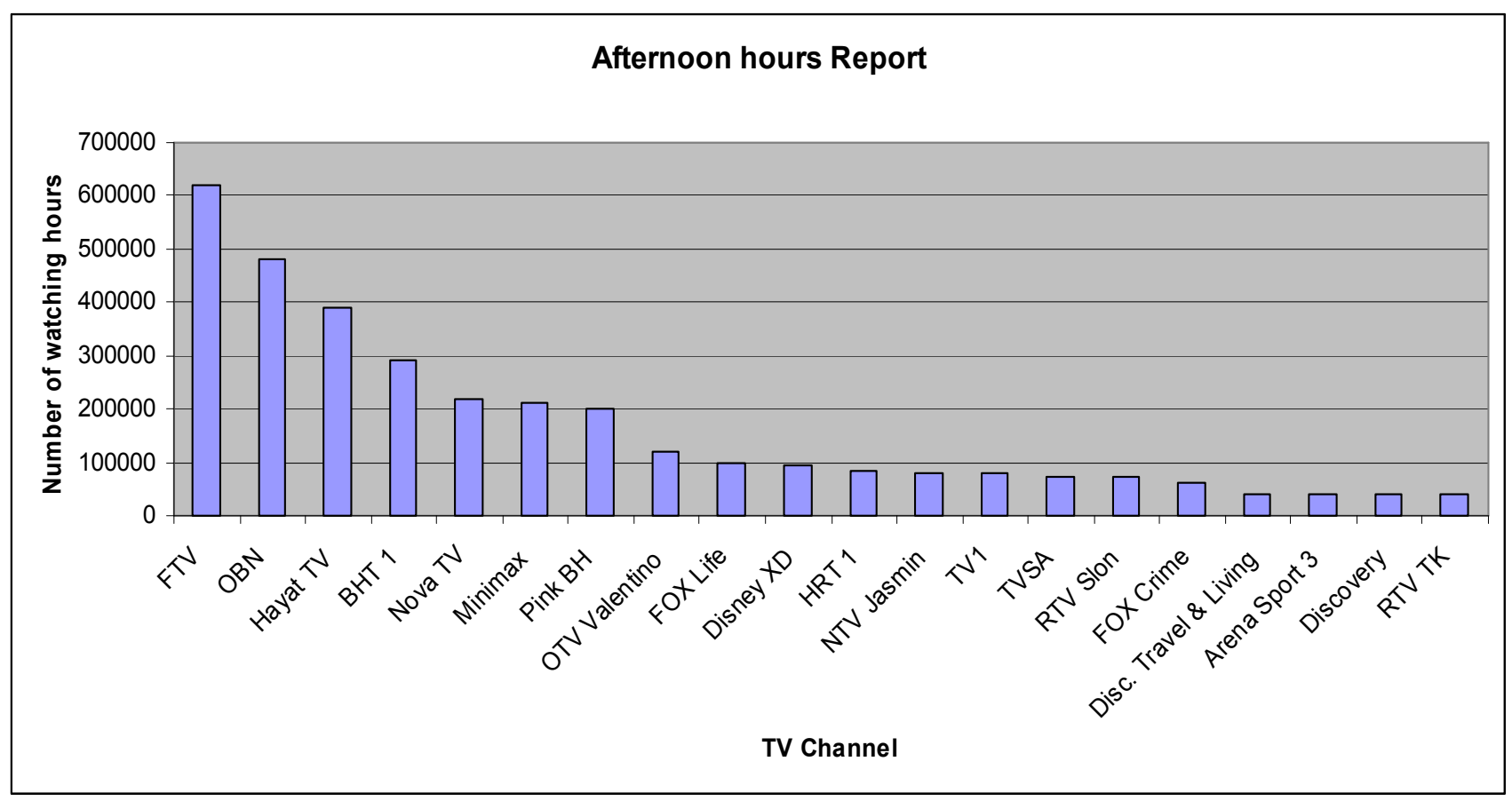

Fig. 10. The most watched TV channels in afternoon hours of month (May 2011.)

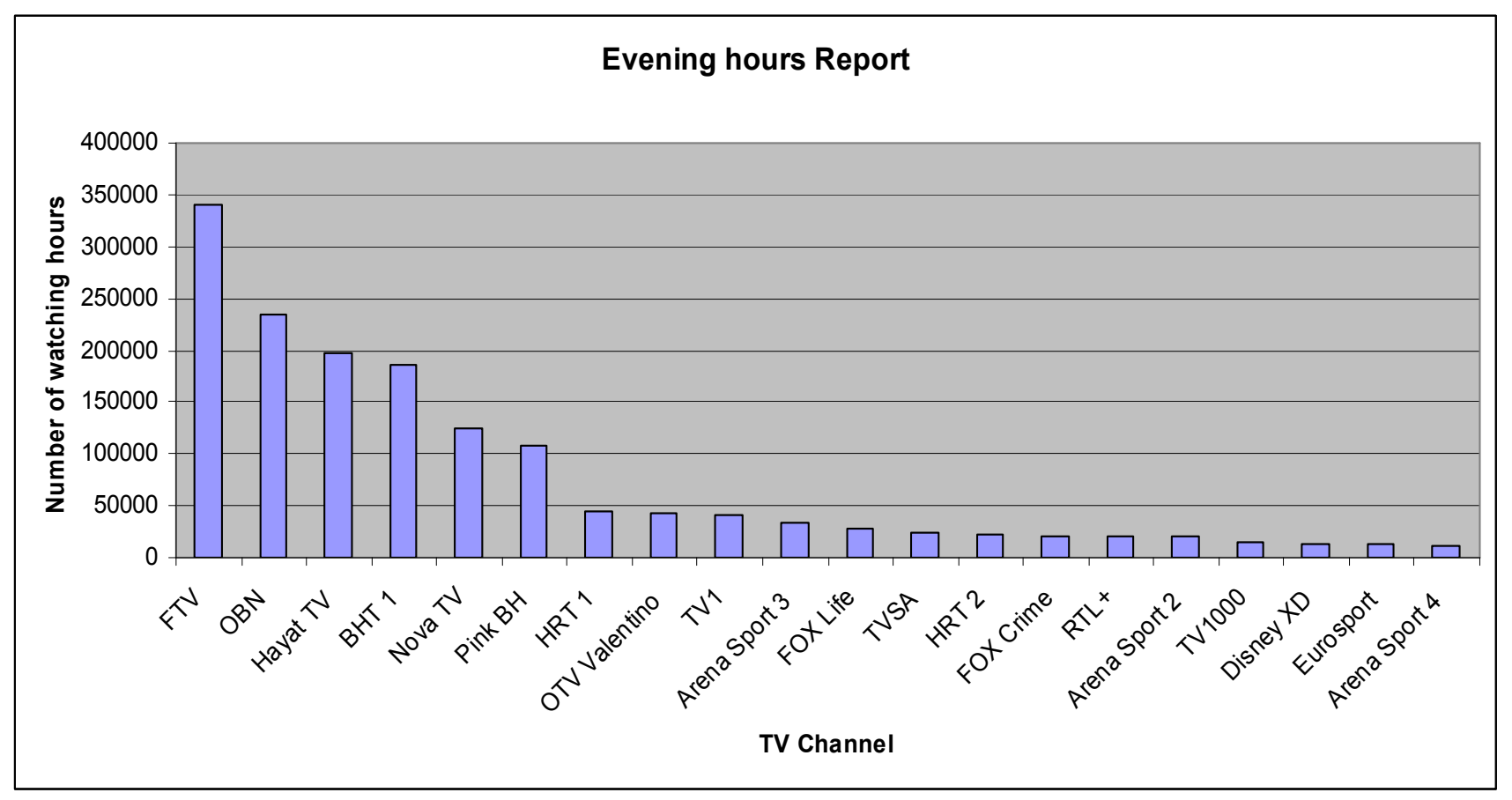

Fig. 11. The most watched TV channels in evening hours of month (May 2011.) 


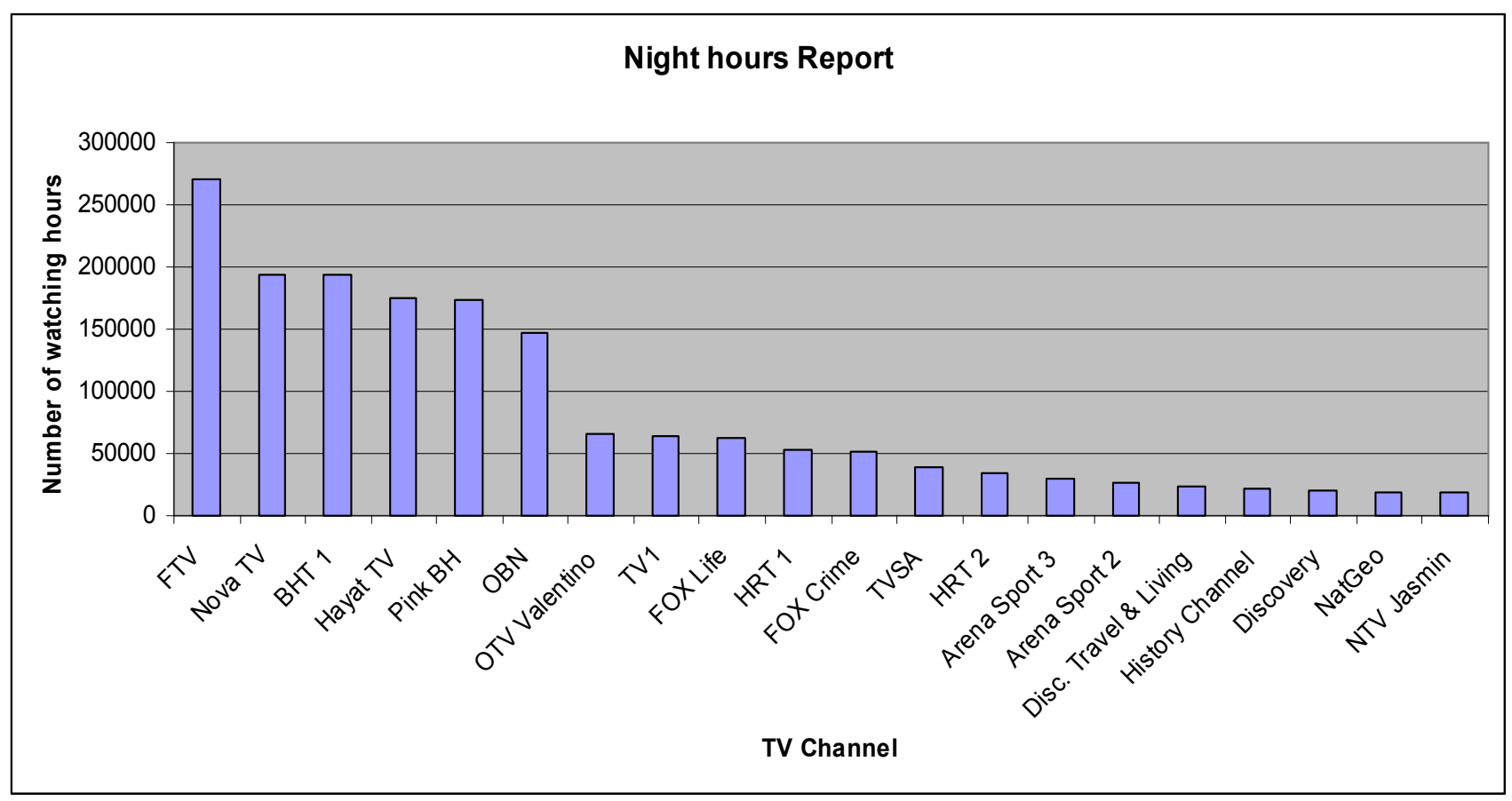

Fig. 12. The most watched TV channels in night hours of month (May 2011.)

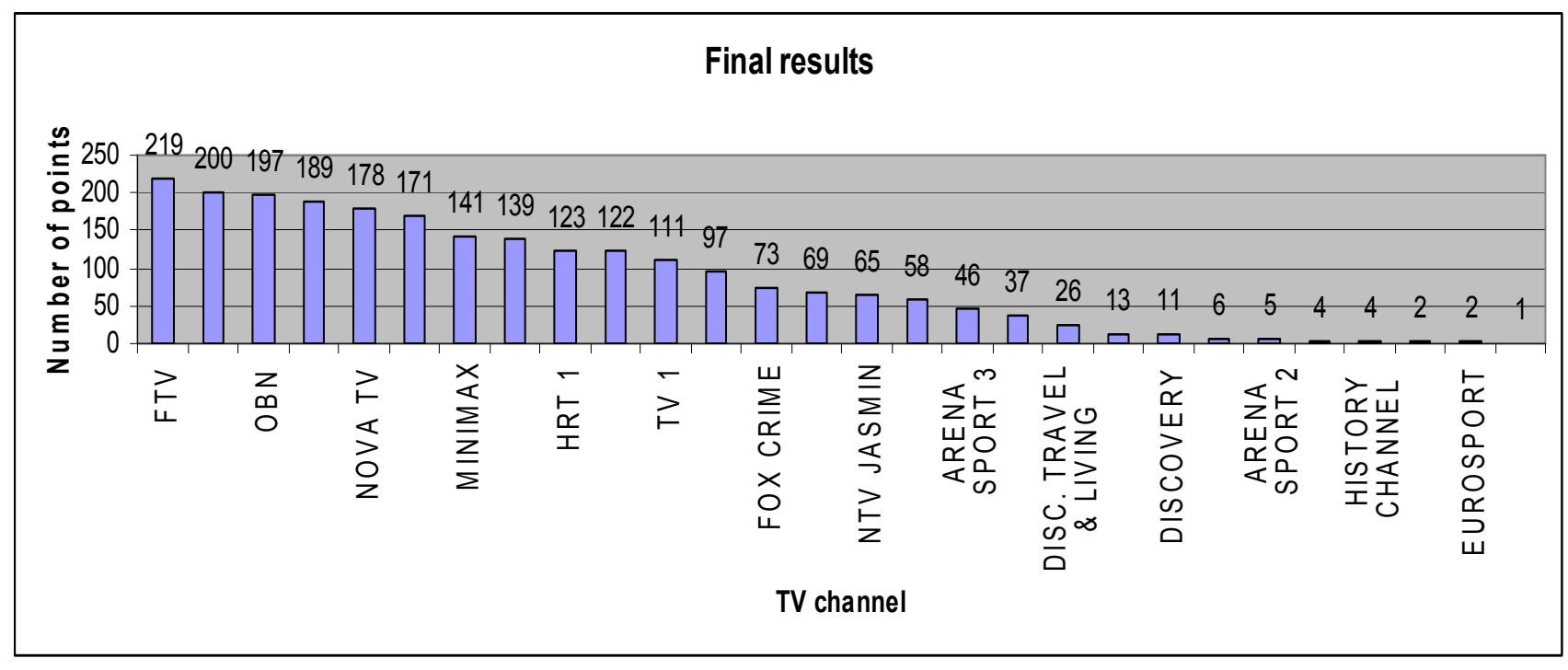

Fig. 13. Final results after all 11 tests

TABLE III. RESULTS FOR IPTV STATISTICS MODEL FOR THIS RESEARCH

\begin{tabular}{|c|c|}
\hline The name of category & Results for each category \\
\hline $1^{\text {st }}$ & $42.5 \%$ \\
\hline $2^{\text {nd }}$ & $30.1 \%$ \\
\hline $3^{\text {rd }}$ & $25.7 \%$ \\
\hline $4^{\text {th }}$ & $1.5 \%$ \\
\hline $5^{\text {th }}$ & $0 \%$ \\
\hline
\end{tabular}




\section{CONCLUSION AND FUTURE WORK}

Comparison of results from Figure 13 and other figures is giving these concluding remarks for Telecom operator from Bosnia and Herzegovina:

1. Final results are totally the same as the results from Figure 2 which considers the most watched TV channels in a month for the first 20 channels except that in the final result TV channel HRT 1 is not on $10^{\text {th }}$ place but on $9^{\text {th }}$ place.

2. Last seven TV channels on final Figure 13 are obtained from Figure 11 which represents the most watched TV channels in the evening hours. It means that for each analysis of the most watched TV channels, evening hours (from 8 p.m. to 11 p.m.) should be placed in the special category.

3. The analysis has shown that $28 \mathrm{TV}$ channels are presented in the final table. The total number of TV channels are 75 , so $47 \mathrm{TV}$ channels are almost not watched.

4. 8 of 10 first TV channels are local TV channels and only Minimax, which is on the $7^{\text {th }}$ place, and Fox Life, which is on the $10^{\text {th }}$ place, are foreign TV channels. Simply conclusion is that local TV channels are more watched than foreign TV channels.

5. There are major differences in ratings between the first $6 \mathrm{TV}$ channels and only minor differences in ratings between channels under the $6^{\text {th }}$ place.

6. First 12 TV channels are only important for the most users (the number of points is 100 and more). This is specific result for this Telecom operator.

This analysis can be used to predict user prefences about watching TV channels in Bosnia and Herzegovina. From previous research we can conclude what TV channels are most watched in: morning hours, afternoon hours, evening hours, night hours or during working days or weekends. In this way this investigation can be one important step for future sociology investigations about users' preferences and wishes during different hours or different days. This research is important step for future not only technical studies but also sociological studies.

Because of future researches in this area and based on results that are produced in this investigation, we proposed a little IPTV statistics model in which all TV channels are divided in 5 categories. In the first category are TV channels with a very high level of watching, in the second category are TV channels with a high level of watching, in the third category are TV channels with a medium level of watching, in the fourth category are TV channels with a low level of watching and in the fifth category are TV channels with a very low level of watching. For Telecom operator with 100 TV channels in the $1^{\text {st }}$ category are first the most watched TV channels, in the $2^{\text {nd }}$ category are TV channels from $6^{\text {th }}$ to $10^{\text {th }}$ place, in the $3^{\text {rd }}$ category are TV channels from $11^{\text {th }}$ to $20^{\text {th }}$ place, in the $4^{\text {th }}$ category are TV channels from $21^{\text {st }}$ place to $50^{\text {th }}$ place and in the $5^{\text {th }}$ category are TV channels from $51^{\text {st }}$ place to $100^{\text {th }}$ place.

The aim is to compare results from the same Telecom operator in different months or from different Telecom operators in the same month. Future research in this area is based on these comparisons.

Table III shows results for IPTV statistics model which are produced in this research. This result shows that all 3 channel categories in this research are almost equally watched.

\section{REFERENCES}

[1] A. Tanovic, I. Androulidakis, "Improving the eTOM standard for Telecom operators", XXIII International Symposium on Information, Communication and Automation Technologies, ICAT 2011, Sarajevo, Bosnia and Herzegovina, 2011.

[2] A. Tanovic, F. Orucevic, "Implementation of the Information System of the Telecom Operator Using the ITIL V3 Methodology for the Service Design Phase", $2^{\text {nd }}$ International Conferences on Advanced Service Computing, SERVICE COMPUTATION 2010, pp. 82 - 91, Lisbon, Portugal, 2010.

[3] A. Tanovic, F. Orucevic, "Changing the Middleware System for IPTV Services Telecom Operators Based on the Methodology of the Change Management Process", $3^{\text {rd }}$ International Conferences on Advances in Multimedia, MMEDIA 2011, pp. 104 - 110, Budapest, Hungary, 2011.

[4] A. Tanovic, F. Orucevic, "Analysis of the implementation of the Information Security Management in the IPTVVoIP system of the Telecom Operator", $18^{\text {th }}$ International Conference on Systems, Signals and Image Processing, IWSSIP 2011, pp. 1-5, Sarajevo, Bosnia and Herzegovina, 2011,

[5] J. Huang, A.B. Lee, D. Mumford, "Statistics of range images", IEEE Conference on Computer Vision and Pattern Recognition, Vol. 1, pp. 324-331, 2000.

[6] P. Gacs, J. T. Tromp, P. M. B. Vitanyi, “Algorithmic statistics", IEEE Transactions on Information Theory, Vol. 47, No. 6, pp. 2443-2463, 2001.

[7] Y. J. Won, Mi-Jung Choi, Byung-Chul Park, J. W. Hong, Hee-Won Lee, Chan-Kyu Hwang, Jae-Hyoung Yoo, "End-User IPTV Traffic Measurement of Residential Broadband Access Networks", IEEE Network Operations and Management Symposium Workshops, NOMS 2008, pp. 95-100, 2008.

[8] T. Zijian, R. C. Cannizzaro, G. Leus, P. Banelli, "Pilot-Assisted Time-Varying Channel Estimation for OFDM Systems", IEEE Transactions on Signal Processing, Vol. 55, No. 5, pp. 2226-2238, 2007

[9] M. K. Tsatsanis, G.B. Giannakis, "Blind identification of timevarying channels using second-order statistics", $29^{\text {th }}$ Asilomar Conference on Signals, Systems and Computers, pp. 162-166, 1995.

[10] M. -J. Montpetit, H. Calhoun, H. Holtzman, D. Grossman, "Adding the Community to Channel Surfing: A New Approach to IPTV Channel Change." 6th IEEE Consumer Communications and Networking Conference, CCNC 2009, pp. 1 - 5, Las Vegas, Nevada, USA, 2009

[11] H. Lin Wang, J. Gang Wang, W. Yun Yau, "Automated age regression for personalized IPTV services", IEEE International Conference on Multimedia and Expo (ICME 2010), pp. 1333-1336, Singapore, 2010. 